\title{
PROSPEK PENGEMBANGAN ILMU EKONOMI ISLAM DI INDONESIA DALAM PRESPEKTIF FILSAFAT ILMU (SEBUAH KAJIAN EPISTEMIK)
}

\author{
Ayief Fathurrahman ${ }^{1}$
}

\begin{abstract}
This article describes the approaches recently being used in developing Islamic Economics, especially in Indonesia. Eventough it grows rapidly in recent years, Islamic economics is still banded by dominance of normative approach. Some reasons can be addresed to this issue mainly the lack of proper approaches in Islamic economics. In order to make Islamic Economics regarded as a proper scientific discipline, it requires more approaches based on rational and empirical studies not only based on theological beliefs of moslem. In its recent development, burhani approach is not still functioned optimally. Therefore, combination of bayani, irfani, and burhani approaches in developing Islamic Economics is an obligated concept.
\end{abstract}

Keywords: Filsafat Ilmu, Ekonomi Islam, Nalar Islami

\section{Pendahuluan}

Eksistensi ekonomi Islam belum begitu dikenal pada sekitar tahun 1950-an apalagi berbentuk sebuah konsep yang termasuk dalam kriteria bangunan disiplin ilmiah. Ketika itu, sedang berlangsungnya zaman keemasan ideologi ekonomi sosialisme dan kapitalisme sehingga sistem ekonomi Islam masih belum bisa menunjukkan eksistensinya sebagai sistem yang kental dengan muatan keadilan dan kebersamaan, walaupun sebenarnya pada masa awal sejarah perkembangan Islam abad ke-7, Islam sudah memiliki sistem ekonomi yang difungsikan sebagai pengatur aktivitas ekonomi. ${ }^{2}$

Seiring dengan berjalannya waktu, sejarah menjadi saksi akan kekeroposan dua sistem yang pernah merajai dunia itu. Sosialisme yang muncul pada abad ke-19 hingga awal abad ke-20 dengan semangat kaum buruh industri dan buruh tani berdasarkan prinsip solidaritas untuk memperjuangkan masyarakat egalitarian dan

\footnotetext{
${ }^{1}$ Penulis adalah Mahasiswa Program Pasca Sarjana Fakultas Ilmu Agama Islam, Universitas Islam Indonesia, pada Program Studi Magister Studi Islam UII, Kosentrasi Ekonomi Islam.

${ }^{2}$ Baca lebih lanjut Muhammad (2009), Ekonomi Islam: Kontribusi Fundamentalisme Islam untuk Ekonomi Islam, Malang: Empatdua, pp. 24-32, dan Adiwarman Azwar Karim (2006), Sejarah Pemikiran Ekonomi Islam, edisi ketiga, (Jakarta : PT Raja Grafindo Persada).
} 
melayani masyarakat banyak daripada hanya segelintir elite ${ }^{3}$, di persimpangan sejarah perjalannanya, semakin menunjukkan arogansi hegemoni yang membabi buta. Hakhak kepemilikan individu dinafikan dengan dalih atas nama kebersamaan sehingga pada akhir riwayatnya, justru menjadi sebuah boomerang tersendiri yang menjungkirbalikkan sistem sosialisme ke arah kehancuran. ${ }^{4}$

Kapitalisme belakangan ini mulai menunjukkan tanda-tanda kehancuran. Semenjak sistem kapitalisme mendominasi sistem perekonomian dunia, hampir semua negara pernah mengalami krisis yang menggoyahkan stabilitas. Krisis demi krisis ekonomi terus berulang dalam sejarah. Tercatat sejak tahun 1923, tahun 1930, tahun 1940, tahun 1970, tahun 1980, tahun 1990, dan dan tahun 1998-2001, bahkan pada tahun 2008 krisis semakin mengkhawatirkan dengan munculnya krisis finansial di Amerika Serikat, yang memberikan efek domino ke berbagai negara di penjuru dunia. ${ }^{5}$ Roy Davies dan Glyn Davies menjelaskan dengan jelas kronologi krisis ekonomi dunia secara menyeluruh. Sepanjang Abad ke-20 telah terjadi lebih 20 kali krisis besar yang melanda banyak negara. Ini berarti, rata-rata setiap 5 tahun terjadi krisis keuangan hebat yang mengakibatkan penderitaan bagi jutaan umat manusia. ${ }^{6}$

${ }^{3}$ Istilah sosialisme atau sosialis dapat mengacu ke beberapa hal yang berhubungan dengan ideologi atau kelompok ideologi, sistem ekonomi, dan negara. Istilah ini mulai digunakan sejak awal abad ke-19. Dalam bahasa Inggris, istilah ini digunakan pertama kali untuk menyebut pengikut Robert Owen pada tahun 1827. Di Perancis, istilah ini mengacu pada para pengikut doktrin Saint-Simon pada tahun 1832 yang dipopulerkan oleh Pierre Leroux dan J. Regnaud dalam l'Encyclopédie Nouvelle. Penggunaan istilah sosialisme sering digunakan dalam berbagai konteks yang berbeda-beda oleh berbagai kelompok. Selengkapnya lihat Wikipedia Bahasa Indonesia (2010), "Sosialisme" dikutip dari http:// id.wikipedia.org/wiki/Sosialisme diakses 15 September 2010.

${ }^{4}$ Dalam perkembangannya, kaum sosialis tumbuh menjadi aliran yang lebih radikal. Ajaran yang digunakan kaum ini lebih berorientasi pada tujuan yang hendak dicapai, yaitu membentuk masyarakat sosialis dunia. Seringkali upaya-upaya yang mereka lakukan keluar jauh dari mainstream paham sosialis. Anarkisme, pembantaian dan bahkan mengorbankan bagian dari golongan mereka sendiri, semua itu sah-sah saja. Lebih lanjut baca A. Qohar Mudzakkir (2008), "Kapitalisme, Sosialisme dan Sistem Ekonomi Indonesia”, dikutip dari http://qahar.wordpress.com/2008/03/29/kapitalismesosialisme-dan-sistem-ekonomi-indonesia/diakses tanggal 15 September 2010.

${ }^{5}$ Situasi ini dipicu oleh terjadinya kredit macet di sektor properti (subprime mortgage) sehingga menyebabkan industri subprime mortgage skala besar seperti American Home Mortgage Investment Corporation (AHMI), Mortgage Guaranty Insurance Corporation (MGIC), dan New Century Financial Corporation (NCFC), jatuh bangkrut. Para investor kehilangan biliyunan dollar untuk mencegah agar aset-aset subprime mortgage tidak lenyap. Tindakan ini kemudian memicu terjadinya huru-hara di pasar finansial global. Lebih lanjut baca Coen Husain Pontoh (2007), "Efek Domino Krisis Properti di AS", dikutip dari http://coenpontoh.wordpress.com/2007/09/19/efek-domino-krisisproperti-di-as/ diakses 15 September 2010.

${ }^{6}$ Roy Davies and Glyn Davies, (1996), The History of Money From Ancient Time of Present Day, New York: Oxford University Press, p. 13. 
Sejumlah fakta dan data di atas menjadi sebuah momentum yang berharga bagi sistem ekonomi Islam untuk membuktikan keunggulan dan keistimewaannya kepada masyarakat dunia. Bank Syariah sebagai perwujudan kelembagaan ekonomi Islam telah memberikan sebuah bukti nyata akan kemampuan bertahan dalam menghadapi badai krisis yang terjadi. Imunitas ini memberikan dampak positif terhadap tingginya tingkat aseptabilitas masyarakat terhadap perkembangan ekonomi Islam, baik pada level nasional maupun international. ${ }^{7}$

Pertumbuhan ekonomi Islam di Indonesia, jika ditelusuri melalui jejak perkembangan perbankan syariah, berkembang relatif cepat menyusul dikeluarkannya peraturan yang mengatur tentang perbankan syariah. ${ }^{8}$ Fakta ini tentunya memberikan angin segar bagi banyak kalangan, bukan saja bagi sebagian besar umat Islam, tetapi juga bagi siapapun yang tertindas oleh falsafah "laissez faire" yang diusung oleh sistem kapitalisme. Pertumbuhan ekonomi Islam yang pesat tersebut, dari sisi lainnya ternyata masih menyimpan persoalan dan menyisakan sejumlah permasalahan, terutama di Indonesia sehingga kritik konstruktif tetap perlu. Fakta yang terjadi di lapangan kerapkali memunculkan pertanyaan-pertanyaan mendasar sebagai respon dari ketidaksiapan ataupun ketidakmampuan ekonomi Islam sebagai sebuah sistem dalam menghadapi perkembangan mutakhir yang semakin komplek.

Alqur'an dan Sunah tidak bisa dipungkiri merupakan sumber khazanah keilmuan dan buku pedoman umat Islam, namun pada saat yang bersamaan harus diakui bahwa perkembangan mutakhir belakangan ini menuntut adanya rekontekstualisasi pelajaran yang terkandung di dalamnya dalam rangka menjawab persoalan umat sebagai konsekuensi zaman yang berbeda demikian juga halnya dengan kompilasi hukum yang disepakati ulama klasik (fikih). Dengan demikian, aturan yang dterapkan akan lebih mudah dipahami, dihayati, dan diamalkan oleh siapa saja dan ajaran-ajaran luhur yang terkandung didalamnya tidak lagi hanya merupakan himbauan moral tapi menjadi suatu sistem tatanan hidup yang dihayati sebagai way of life dan rule

${ }^{7}$ Ayief Fathurrahman, "Meninjau Ulang Landasan NormatifPerbankan Syariah Di Indonesia (Telaah Atas Teori Kontruksi Fikih Klasik)", Jurnal Mawarid Vol. XI, No.1 Februari-Agustus 2010.

${ }^{8}$ Biro Perbankan Syariah-Bank Indonesia sejak tahun 2001 telah melakukan kajian dan menyusun Cetak Biru Pengembangan Perbankan Syariah Indonesia untuk periode 2002 - 2011. Adapun cetak biru ini disusun dengan tujuan untuk mengidentifikasi tantangan utama yang akan dihadapi oleh industri perbankan syariah pada tahun-tahun mendatang. Dalam cetak biru tersebut terdapat visi dan misi pengembangan perbankan syariah, inisiatf-inisiatif terencana dengan tahapan yang jelas untuk mencapai sasaran yang ditetapkan. Sasarannya antara lain berupa terpenuhinya prinsip syariah dalam operasional perbankan; diterapkan prinsip kehati-hatian; terciptanya sistem perbankan syariah yang kompetitif; terciptanya stabilitas sistemik serta terealisasinya kemanfaatan bagi masyarakat luas. Baca lebih lanjut Bank Indonesia (2002), Cetak Biru Pengembangan Perbankan Syariah Indonesia, Jakarta : Direktorat Perbankan Syariah Bank Indonesia.

${ }^{9}$ Penolakan terhadap campur tangan negara dalam aktivitas ekonomi sebagai prasyarat terjaminnya mekanisme pasar bebas. 
of game yang dipatuhi. Dengan cara itulah ajaran agama akan benar-benar membawa dampak nyata bagi peningkatan kesejahteraan manusia. ${ }^{10}$

Pengembangan ekonomi Islam tentunya tidak terlepas dari hakikat tujuan penyusunannya sendiri. Ekonomi Islam muncul sebagai sistem alternatif yang dianggap mampu mewujudkan tatanan kehidupan yang sampai saat ini masih menyisakan berbagai permalahan fundamanetal. Dampak yang disumbangkan oleh sistem kapitalisme seperti kemiskinan, kelaparan adalah persoalan mendasar yang masih ada di dunia ini. Jeremy Seabrook menuturkan bahwa kemiskinan global bukanlah soal kekurangan sumber daya, melainkan suatu akibat digenggamnya kendali ekonomi oleh negara-negera kaya. ${ }^{11}$

Berangkat dari latar belakang di atas dan dalam rangka mewujudkan sistem ekonomi Islam yang mampu menghantarkan manusia ke puncak peradaban, maka mau tidak mau, kerja keras ekonom dan agamawan sangat dituntut untuk merumuskan pendekatan ataupun metode yang multidimensi, bukan saja sebatas ilmu yang mengajarkan etika dan nilai, tetapi juga menghasilkan postulat-postulat brilian untuk kesejahteraan manusia.

Filsafat Ilmu sebagai sebuah metode pengelaborasian karakteristik disiplin ilmiah (scientific discipline) dan bagaimana cara memperolehnya (epistimic), menjadi hal yang sangat mungkin untuk dijadikan salah satu referensi dasar di samping referensi fundamental (Alquran dan Sunah) sebagai pengembangan ekonomi Islam. Hal ini mengingat ekonomi Islam baik secara substantif maupun historis juga bagian dari ilmu pengetahuan yang berkembang dan dinamis di atas rute perjalanan realitas yang mengitarinya.

\section{Pertumbuhan Ekonomi Islam di Indonesia}

Ekonomi Islam mengalami perkembangan dan kemajuan yang pesat setelah berdirinya Islamic Development Bank (IDB) di Jeddah pada tahun 1975. Hal ini mampu menarik perhatian dan mempengaruhi peta pemikiran praktik keuangan global secara signifikan. Diskursus dan praktek ekonomi Islam mampu memikat kalangan akademisi, professional, maupun praktisi yang berkecimpung dalam perekonomian pada level international. Kajian-kajian tentang ekonomi dan keuangan Islam berkembang bukan saja di negara-negara mayoritas muslim tetapi juga merambah hingga ke negara-negara Barat.

Munculnya ekonomi Islam secara formal di Indonesia ditandai dengan berdirinya Bank Muamalat Indonesia (BMI) pada tahun 1992 berdasarkan UU No. 7

${ }^{10}$ Muhammad Iswadi (2007), “Ekonomi Islam: Kajian Konsep dan Model Pendekatan”, Jurnal Mazabib, Vol. IV, No. 1, Juni 2007, pp. 48-57.

${ }^{11}$ Jeremy Seabrook (2006), Kemiskinan Global: Kegagalan Model Ekonomi Neoliberalisme, Yogyakarta: Resist Book, p. 69. 
tahun $1992 .{ }^{12}$ Kendatipun isu tentang ekonomi Islam relatif terlambat masuk, namun ada antusiasme yang kuat untuk mempelajarinya. Perkembangan kajian ilmiah di Indonesia sangat beragam dan dinamis, karena telah melibatkan perguruan tinggi negeri dan swasta, baik yang dimiliki umat Islam maupun non-Muslim. Menurut data majalah Sharing per April 2009, terdapat 52 perguruan tinggi yang mengajarkan ekonomi Islam di bawah Departemen Agama maupun Departemen Pindidikan Nasional.Jenjang pendidikan terdiri dari diploma, sarjana, pasca sarjana, sampai jenjang doktoral. ${ }^{13}$

Lembaga keuangan syariah juga tumbuh pesat sejak tahun 2000-an sampai saat ini, di berbagai daerah dengan basis terbesar di Jawa, disusul Sumatera, Sulawesi dan Kalimantan. Baitul Mal wa Tamwil (BMT) sebagai lembaga yang bergerak di bidang jasa pelayanan keuangan di kelas mikro syariah, sampai pada tahun 2010 ini jumlahnya mencapai kurang lebih 3.400 BMT yang tersebar di seluruh wilayah Indonesia.

Selain itu, pertumbuhan perbankan syariah nasional juga relatif cepat setelah dikeluarkannya peraturan yang mengatur tentang perbankan syariah dan dilakukannya kajian serta menyusun Cetak Biru Pengembangan Perbankan Syariah Indonesia untuk periode 2002-2011. Cetak biru ini disusun untuk mengidentifikasi tantangan utama yang akan dihadapi oleh industri perbankan syariah pada tahun-tahun mendatang. Di dalamnya terdapat visi dan misi pengembangan perbankan syariah, inisiatif-inisiatif terencana dengan tahapan yang jelas untuk mencapai sasaran yang ditetapkan. Sasarannya antara lain berupa terpenuhinya prinsip syariah dalam operasional perbankan; diterapkan prinsip kehati-hatian; terciptanya sistem perbankan syariah yang kompetitif; terciptanya stabilitas sistemik serta terealisasinya kemanfaatan bagi masyarakat luas. ${ }^{14}$

Pengembangan sistem perbankan syariah di Indonesia dilakukan dalam kerangka dual-banking system atau sistem perbankan ganda dalam kerangka Arsitektur Perbankan Indonesia (API), untuk menghadirkan alternatif jasa perbankan yang semakin lengkap kepada masyarakat Indonesia. Secara bersama-sama, sistem perbankan syariah dan perbankan konvensional secara sinergis mendukung mobilisasi dana masyarakat secara lebih luas untuk meningkatkan kemampuan pembiayaan bagi sektorsektor perekonomian nasional. ${ }^{15}$

${ }^{12}$ Terdapat beberapa versi tentang hal ini, diantara yaitu lahirnya BMI hanya sebagai bentuk akomodasi pemerintah kepada kaum muslimin, mengingat kaum muslimin merupakan agama mayoritas. Pendirian BMI termasuk teori akomodasi pemerintah yang bersifat infrastruktur, selain struktural, legislatif, dan kultural. Lebih lanjut baca Bahtiar Effendy (1998), Islam dan Negara: Transformasi Pemikiran dan Praktik Politik Umat Islam di Indonesia, Jakarta: Paramadina, pp. 269-310 dan Fahcry Ali (1991), "Akomodasi Non-Politik Islam Indonesia dalam Struktur Orde Baru”, Prisma, Vol. 20 No. 3, Maret 1991, pp. 87-96.

${ }^{13}$ Sharing, Majalah Ekonomi dan Bisnis Syariah Edisi 28 Thn III April 2009, p. 25.

${ }^{14}$ Bank Indonesia (2002), Cetak Biru Pengembangan...p. 15.

${ }^{15}$ Zulkarnain Sitompul (2002), "Kemungkinan Penerapan Universal Banking System di In- 
Fakta dan data di atas tentu saja menjadi berita gembira bagi banyak kalangan. Perkembangan menggembirakan ini sudah selayaknya dijadikan motivasi dan kekuatan untuk menyempurnakan ekonomi islam, baik sebagai sistem maupun sebagai sebuah ilmu yang mendasari aktivitas perekonomian secara keseluruhan. Landasan normatif yang terdiri dari Alquran, Sunah, fikih masih menjadi pokok utama dalam pembahasan ekonomi Islam. Ringkasnya, pendekatan yang ditawarkan ekonomi Islam cenderung diterapkan secara normatif-idealis-deduktif, sehingga pada gilirannya ekonomi Islam hanya terkesan sebagai sistem yang mengkritik tanpa menyertai tawaran teori dan sistem yang berarti. Dengan kata lain, ekonomi Islam relatif masih berjalan pada ranah hukum halal atau haram, sementara sistem ekonomi lain, seperti kapitalisme, liberalisme, neo-liberal, sosialisme sudah berbicara pada tataran praktis yang juah lebih maju.

Pendirian berbagai lembaga keuangan syariah di berbagai wilayah tidak serta merta menjadi bukti bahwa ekonomi Islam pasti akan menyingkirkan sistem ekonomi kapitalisme yang saat ini masih menjadi sistem utama dalam tatanan ekonomi global. Tanpa disertai dengan sistem yang canggih, program yang memadai, produk yang unggul dan teori-teori yang teruji, walaupun sampai kapan pun, ekonomi Islam hanya akan ada dalam sistem perbankan sebagaimana kita saksikan sekarang. Hal ini tentu menyederhanakan tujuan ekonomi Islam itu sendiri, yang pada hakikatnya mempunyai misi dan visi relatif jauh lebih luas cakupanya.

Pemikir, ekonom muslim, maupun agamawan seharusnya lebih bersikap agresif dalam mengelaborasi pemikiran konstruktif pengembangan ekonomi Islam. Tanpa hal tersebut, akan terdapat beban berat bagi pertumbuhan ekonomi Islam sehingga menghambat hakikat tujuan terwujudnya ekonomi yang berkeadilan. Meskipun akhir-akhir ini terdapat banyak literatur tentang ekonomi Islam, nampaknya masih jauh ketinggalan dengan literatur-literatur sistem ekonomi lainnya. Dengan demikian, para ekonom muslim seharusnya tetap berupaya dengan sekuat tenaga untuk mengembangkan ekonomi Islam, bukan hanya pada tataran praktis saja tetapi juga pada wilayah teori yang dirasa masih relatif kurang demi mengejar ketertinggalan dan tentunya teori yang sudah jauh melewati pembahasan halal-haram.

\section{Ekonomi Islam: Antara Doktrin dan Ilmu}

Dampak negatif dari kemajuan ilmu pengetahuan dan teknologi yang ditorehkan oleh peradaban Barat menghiasi kekusutan patologi sosial. Ketidakadilan, eksploitasi, dehumanisasi, dan mafsadat menjadi realitas yang inheren dengan kehidupan manusia modern. Keadaan ini menuntut munculnya wacana Islamisasi ilmu pengetahuan yang ramai diperbincangkan pada tahun 1970-an oleh para sarjana Mus-

donesia: Kajian dari Perspektif Bank Syariah", Jurnal Hukum Bisnis, Vol 20, Agustus-September 2002, p. 1-9, dikutip dari http://zulsitompul.files.wordpress.com/2007/06/bank-syariahjhb.pdf diakses tanggal 15 September 2010. 
lim dari berbagai disiplin ilmu. Upaya menggali nilai-nilai Islam ini dapat dibaca sebagai sebuah kontra-hegemoni ataupun diskursus perlawanan. ${ }^{16}$ Ekonomi sebagai salah satu disiplin ilmu pengetahuan menjadi sasaran yang sering diperbincangkan. Sebab ilmu ini tak hanya berhenti pada tataran akademis dan perdebatan metodologis, melainkan juga masuk ke wilayah praktis. ${ }^{17}$

Pada kenyataannya, di balik kisah sukses Islamisasi, terutama kaitannya dengan perkembangan ekonomi Islam yang merata di belahan dunia, khususnya di Indonesia, ada segumpal cerita pilu yang menarik untuk dikaji. Mulai dari kisah penipuan yang melanda sebagian besar lembaga keuangan syariah lantaran ketiadaan sistem yang memadai, kemiskinan literatur dan teori ilmiah sebagai khazanah keilmuan ekonomi Islam, hingga ketidaksesuian landasan normatifnya dengan kedinamisan realitas yang senantiasa berubah-ubah. Belum lagi persoalan pragmatisme sebagai dampak dari realitas pasar yang mendorong berdirinya ribuan lembaga ekonomi syariah dan dibukanya program studi ekonomi Islam, ${ }^{18}$ sehingga pada gilirannya memunculkan dilema dalam memahami hakikat ekonomi Islam itu sendiri. Fakta ini, sering kali mengaburkan pemahaman untuk membedakan secara tegas-proporsional dimana wilayah keilmuan dan dimana wilayah keagamaan.

Pada konteks prospek pengembangannya, fakta di atas tentu saja menjadi persoalan, dua wilayah yang berbeda akan berimplikasi pada sifat yang relatif berbeda pula. Sifat keilmuan yang menuntut sikap kritis, objektif, dan rasional, berhadapan dengan sikap keagamaan yang lebih menekankan pada subjektivitas, taqlidy, commitment..$^{19}$

Adanya ketegangan tersebut, sejatinya tidak perlu dirisaukan lantaran sebenarnya didalamnya terkandung dinamika yang secara dialektis memberi manfaat bagi kedua sisi tuntutan tersebut. Maka masing-masing mempunyai fungsi dan perannya sendiri, tanpa harus menepikan yang satu dengan yang lainnya. Jika salah satu sisi mencoba mendomisansi eksistensi yang lain, maka ketegangan yang kreatif tersebut berubah menjadi dominasi yang mematikan. Atau sebaliknya, para ilmuan kurang apresiatif

${ }^{16}$ Gagasan atau gerakan Islamisasi ilmu pengetahuan merupakan salah satu upaya menjawab tantangan modernitas yang melanda umat Islam. Ada semacam guncangan di kalangan umat Islam menyaksikan realitas yang menempatkan diri mereka pada sudut buram sejarah. Di balik kemegahan peradaban Barat yang terus melaju pasca Renaissance, sebagian besar dunia Islam secara kontras justru termegap-megap dalam sesuatu yang dalam visi modern disebut perangkap kemunduran dan keterbelakangan. Baca lebih lanjut Yusdani (2007), "Islamisasi Model al-Faruqi dan Penerapannya dalam Ilmu Ekonomi Islam di Indonesia (Suatu Kritik Epistemik)", Jurnal Ekonomi Islam La Riba, Vol.1, No.1, pp. 77-94.

${ }^{17}$ Yusdani (2007), ibid.

${ }^{18}$ ibid.

${ }^{19}$ Untuk lebih mendalam baca Ian G. Barbour (1966), Issues in Science and Religion, New York: Harper and Torch Book, pp. 218-229 
pada nilai-nilai keagamaan yang sui generis, yang amat berfungsi dalam kehidupan keseharian manusia. ${ }^{20}$

Fakta dan data membuktikan bahwa perkembangan ekonomi Islam agaknya masih lebih terbebani dengan misi keagamaan, yang bersifat memihak dan cenderung subjektif sehingga pada gilirannya kadar kekritisan, terutama dalam menelaah naskah keagamaan, misal fikih muamalah, relevansinya dengan kekinian tidak begitu nampak ditonjolkan. Hal ini terlihat jelas ketika adanya unsur pemaksaan untuk menerapkan begitu saja model-model transaksi fikih ke dalam praktek ekonomi modern yang lebih sering bersifat ideologis ketimbang obyektif ilmiah. Hal itu justru kontra-produktif dalam upaya penyusunan bangunan ekonomi Islam itu sendiri. ${ }^{21}$

Dengan demikan, sebelum melangkah lebih jauh, diperlukan adanya keseimbangan yang selaras antara paradigma pengembangan ekonomi Islam yang didasarkan realitas yang rasionalistik-empiris dengan muatan transendental dan metafisis. Dengan kata lain, berpikir secara induktif yang berangkat dari dialog terhadap realitas, merupakan kunci yang tidak bisa ditawar-tawar lagi. Karena dengan begitu, ekonomi Islam dengan sifat komplementer dan suplementernya dapat menjadi kekuatan untuk membangun ekonomi dan sains yang berbasis nilai.

\section{IV.Peranan Filsafat Ilmu terhadap Ilmu Pengetahuan}

Filasafat ilmu adalah proses penyelidikan tentang ciri-ciri pengetahuan ilmiah dan cara untuk memperolehnya. Terdapat banyak pendapat yang mencoba mendeskripsikan makna serta penekanan mengenai pengertian maupun format dari filsafat ilmu. Benyamin mengemukakan bahwa filsafat ilmu adalah $:^{22}$

"Thatphilosophic discipline which is the systematic study of the nature of science, especially of its methods, its concept and presuppositions, and itsplace in the general shame of intellectualdiciplines".

Sebagaimana dikutip di atas filsafat ilmu merupakan cabang ilmu pengetahuan filsafati yang merupakan telaah sistematis mengenai sifat dasar ilmu, khususnya metode, konsep, dan peranggapannya, serta letaknya dalam kerangka umum dari cabang pengetahuan intelektual. Kajian yang dibahas dalam filsafat ilmu adalah meliputi hakekat (esensi) pengetahuan. Artinya filsafat ilmu lebih menaruh perhatian terhadap problem-problem mendasar ilmu pengetahuan. Suriasumantri membagi ke dalam tiga

${ }^{20}$ M. Amin Abdullah (1995), Falsafah Kalam di Era Postmodernisme, Yogyakarta: Pustaka Pelajar, p. 227.

${ }^{21}$ A. Dimyati (2007), "Ekonomi Etis: Paradigma Baru Ekonomi Islam”, Jurnal Ekonomi Islam La Riba Vol.1, No.2, Desember 2007, pp. 153-168.

${ }^{22}$ The Liang Gie (2000), Pengantar Filsafat Ilmu, Edisi Kedua, Cetakan Kelima, Yogyakarta: Liberti. 
landasan pokok pertanyaan mengenai hakikat ilmu, yaitu landasan ontologis ilmu, landasan epestimologis ilmu, dan landasan aksiologis ilmu. ${ }^{23}$

Perkembangan ilmu pengetahuan sebagai hasil kreatif usaha pemahaman manusia yang sistematis, menghasilkan prestasi yang luar biasa. Namun pada saat yang bersamaan, memunculkan sebuah dilema yang memberikan sebuah kekhawatiran kepada berbagai kalangan ilmuwan, filsuf, dan agamawan bahwa kemajuan iptek tersebut dapat mengancam eksistensi umat manusia, bahkan alam beserta isinya. Ilmu pengetahuan seolah belari dengan cepat ditengah gelap gulita tanpa lampu penerangan sehingga memunculkan arogansi tanpa perhitungan, bahkan benturan yang tidak sehat antara satu bidang ilmu dengan yang lain. Fakta ini menunjukkan agaknya pengembangan ilmu pengetahuan dan teknologi berjalan terlepas dari asumsi-asumsi dasar filosofisnya seperti landasan ontologis, epistimologis, aksiologis yang cenderung berjalan sendiri-sendiri. Kehadiran filasat ilmu merupakan upaya meletakkan kembali peran dan fungsi ilmu pengetahuan dan teknologi (iptek) sesuai dengan tujuan semula yaitu demi kebahagiaan umat manusia dan kemudahan dalam menjalankan aktivitasnya.

Manusia dengan kemampuan akalnya menghasilkan kemajuan yang pesat di bidang ilmu pengetahuan dan teknologi modern, terutama setelah memasuki abad ke-20. Dalam perkembangannya, ilmu pengetahuan dan teknologi yang seakan-akan menjadi tumpuan harapan manusia dalam menghadapi persoalan hidup ternyata belum dan tidak akan mampu menyelesaikan persoalan hidup dan kehidupan itu. Hal ini terlihat pada peristiwa-peristiwa yang diamati dalam kehidupan umat manusia dewasa ini yang terperosok ke dalam dilema; antara modernisasi dan ketidakadilan. ${ }^{24}$

Sebagai contoh, ekonomi konvensional, lahir dari paradigma enlightenment yang ditandai dengan pendekatan utama untuk mewujudkan kesejahteraan manusia serta analisisnya tentang problem-problem manusia yang bersifat sekuler. Sekuler di sini dimaksudkan sebagai sistem yang lebih mementingkan konsumsi dan pemilikan materi sebagai sumber kebahagiaan manusia, tanpa mengindahkan peranan nilai moral dalam reformasi individu dan sosial, terlalu berlebihan menekankan peranan pasar atau negara. Ia tidak memiliki komitmen kuat kepada persaudaraan (brotherhood) dan keadilan sosioekonomi dan tidak pula memiliki mekanisme filter nilai-nilai moral. ${ }^{25}$

Berangkat dari ideologi yang demikian, impelementasi sistem ekonomi kapitalisme di berbagai belahan dunia, justru menimbulkan kisah-kisah pilu yang memprihatinkan. Saat orang kaya semakin kaya, pendapatan menengah meningkat, dan lebih banyak yang miskin kian melarat. Kenyataan ini menjadikan kemiskinan

${ }^{23}$ Juhaya S. Praja (2000), Filsafat Ilmu: Menelusuri Struktur Filsafat Ilmu dan Ilmu-ilmu Islam, (Bandung: Program Pasca Sarjana Institut Agama Islam Negeri (IAIN) Sunan Gunung Djati), p. 10.

${ }^{24}$ Agustianto (2007), "Kegagalan Kapitalisme: Perspektif Ekonomi Islam”, dikutip dari www.waspadaonline.com diakses 9 Desember 2007, dikutip dalam A. Dimyati (2007), ibid.

${ }^{25}$ Suriasumantri. (1993), Filsafat Ilmu: Sebuah Pengantar Populer, Jakarta: Pustaka Sinar Harapan. 
sebagai suatu yang abadi. Ironisnya, kemiskinan hanyalah sebatas figuran dalam drama kemajuan yang dituturkan dengan pertunjukkan terpilih dari konglomerasi komunikasi global. Sudah menjadi rahasia umum, bahwa orang-orang miskin menjadi strategi utama semua politikus, institusi international, dan lain sebagainya, sehingga pada gilirannya, akan membuat orang miskin kian tak berharga. ${ }^{26}$

Ideologi kapitalisme di atas, dituding oleh berbagai pihak sebagai biang kehancuran yang mengarah pada proses musnahnya hakikat manusia dan menjebak manusia pada disiplin ketat yang mengatur dirinya untuk bisa memenuhi tuntutan kerja keras melebihi yang menjadi kesanggupannya. Nilai-nilai individualisme yang mendasarinya ditempatkan diatas nilai-nilai altruisme, dimana kebersamaan masyarakat menjadi pudar. ${ }^{27}$ Inilah bukti ketika ilmu sudah melangkah jauh seumpama anak ayam yang jauh dari induknya. Nilai-nilai yang adil, etis, dan egaliter, tidak lagi menjadi ruh mengembangkan keilmuan. Tetapi justru nilai-nilai yang individualistik, hedonistik, dan materealistik yang mendasari derap langkah dalam mencapai tujuannya. Dan jelas, persoalan kemanusiaan yang akan menjadi taruhannya. Inilah yang mendasari munculnya rasa kekhawatiran yang cukup rasional dari berbagai kalangan ilmuan.

Peran filsafat ilmu dalam pengembangan ilmu pengetahuan tidak bisa tidak, memang menjadi sebuah keharusan. Perannya sebagai pagar yang membatasi dari sebuah gejala overdosis yang bisa mematikan. Landasan ontologis, epestimologis, dan aksiologis menjadi sangat penting dalam pengembangan ilmu sehingga memiliki daya guna dan makna bagi keberlangsungan hidup manusia.

\section{Pengembangan Ilmu Ekonomi Islam Ditinjau dari Perspektif Filsafat Ilmu}

Lahirnya sistem ekonomi Islam pada pertengahan dasawarsa 70-an, merupakan sebuah respon dari dampak negatif ilmu ekonomi yang dikembangakan oleh ilmuan Barat. Jargon yang diusung adalah maksimalisasi tanpa harus melirik siapa saja yang terlindas oleh roda individulistik, materialistik, dan hedonistik. ${ }^{28}$ Ketidakadilan, ketimpangan, kemiskinan, dan kelaparan merupakan sebagian fenomena yang sudah tidak aneh lagi untuk disaksikan.

Perkembangan ekonomi Islam, jika ditelusuri sejak zaman Nabi atau setidaknnya dari tahun 70-an hingga zaman kontemporer sekarang menunjukkan terjadinya perkembangan yang signifikan dalam body of Islamic economics. Namun di pihak lain, dominanisasi praktek ilmu ekonomi Islam semakin menajam di sektor perbankan dan misi keagamaan, yang bersifat memihak, subjektif, sehingga mendorong adanya unsur pemaksaan untuk menerapkan begitu saja model-model transaksi fikih

${ }^{26}$ Jeremy Seabrook (2006), Kemiskinan Global..., pp. 1-15

${ }^{27}$ Muhammad (2009), Ekonomi Islam..., p. 2

${ }^{28}$ Sjafri Sairin, dkk (2002). Pengantar Antroplogi Ekonomi (Yogyakarta: Pustaka Pelajar Offset), p. 16. 
yang lebih sering bersifat ideologis ketimbang obyektif ilmiah ke dalam praktek ekonomi modern. Hal itu hanya akan mewujudkan sistem ekonomi Islam yang amaliah saja, tanpa ada unsur ilmiahnya. Keadaan semacam inilah yang perlu diatasi dengan strategi pengembangan ilmu dan kajian yang lebih mendalam.

Sejarah pemikiran dan perkembangan ekonomi Islam telah membuka cakrawala pengetahuan kita bahwa ilmu ekonomi Islam bukanlah barang jadi yang hanya selesai dalam satu kali proses atau pun langsung turun dari langit secara mendadak. Ekonomi Islam lahir melalui proses bertahap dan evolutif sehingga bukanlah sebuah kesalahan jika ditinjau kembali secara kritis berdasarkan realitas yang ada dan berkembang. Beragam realitas sudah barang tentu sedikit banyak terlibat dalam melukiskan panorama bangunan ekonomi Islam hingga turut serta dalam mengendalikan haluannya. Kondisi masyarakat dari masa ke masa yang berubah-ubah merupakan hal utama dalam menciptakan fleksibelitas kebijakan ekonom muslim dalam menciptakan kesejahteraan bersama. ${ }^{29}$

Keterikatan nilai-nilai yang diajarkan agama dengan pengembangan ilmu ekonomi merupakan sebuah keharusan. Namun masalahnya adalah bagaimana menempatkan agama agar bisa dihayati secara utuh dengan menjadikan nilai-nilai yang terkandung didalamnya sebagai ruh pengembangan ilmu ekonomi, agar tidak menimbulkan kemudaratan bagi umat manusia. Ketika metodologi ilmiah sudah tidak lagi terlalu diperhatikan dalam rangka konseptualisai ilmu ekonomi Islam karena dominannya wilayah keagamaan, maka ketika itu pula akan terjadi persoalan yang harus dibicarakan lebih mendalam. Apalagi, sebenarnya selama ini wilayah keagamaan yang dianggap oleh sebagian pihak adalah hanyalah hasil rasionalisasi ulama klasik terdahulu, seperti fikih, ilmu tafsir dan sebagainya. ${ }^{30}$

Berdasarkan fakta di atas, maka diperlukan adanya keselarasan antara wilayah keagamaan dengan wilayah keilmuan sehingga agama tidak lagi menjadi kambing hitam atas tafsiran ulama yang sudah tidak lagi relevan dengan zamannya lantaran bertentangan dengan keilmuan modern yang sudah barang tentu berbeda dengan keilmuan klasik. Dengan kata lain, pendekatan yang ditawarkan adalah pendekatan

${ }^{29}$ Ayief Fathurrahman (2010), "Memahami Kebijakan Ekonomi Politik Tiga Khalifah (Ekplorasi Pemikiran Umar bin Khattab, Umar bin Abdul Aziz, Ghazan Khan sebagai Dasar Pengembangan Ekonomi Islam)", dikutip dari http://ayieffathurrahman.wordpress.com/2010/11/22/ memahami-kebijakan-ekonomi-politik-tiga-khalifah-eksplorasi-pemikiran-ekonomi-umar-bin-khattabumar-bin-abdul-aziz-dan-ghazan-khan-sebagai-dasar-perkembangan-ekonomi-islam/ diakses tanggal 22 November 2010.

${ }^{30}$ Menurut Ibnu Taimiyah bahwa ilmu dibagi kepada dua cabang besar: pertama ilmu tentang Allah; dan kedua ilmu tentang segala yang ada: makhluk-makhluk Allah. Ilmu kedua ini menurutnya dapat dipersamakan dengan ilmu dalam pengertian ilmu menurut para pakar ilmu modern, yakni ilmu yang diperoleh melalui prosedur metode ilmiah. Baca lebih lanjut dalam Juhaya S. Praja (2000), Filsafat Ilmu..., p. 6 
yang melibatkan dua model sekaligus: normatif-idealis-deduktif dan historis-emipirisinduktif. ${ }^{31}$

Berkaitan dengan hal di atas, kisah bantahan dogma gereja atas ilmu pengetahuan pada abad pertengahan karena tafsir yang salah dapat dijadikan sebagai sebuah pelajaran. Fakta sejarah ini telah memancing reaksi tersendiri bagi ilmuan Barat pada khususnya, sehingga menampakkan kecenderungan untuk menangkis adanya intervensi agama dalam mengembangkan ilmu pengetahuan. Agama sebagai sumber nilai kemudian dipandang sebagai sebuah ilusi yang tidak mampu menjawab berbagai rintangan dan tantangan kehidupan modern yang serba kompleks. Sigmund Freud, bahkan lebih lantang mengemukakan bahwa agama merupakan ilusi yang didasarkan pada kehendak manusia (buman wishes) daripada realitas. Karena itu, agama mempunyai masa depan yang suram karena tidak cocok dengan kecenderungan ilmiah rasional dan akhirnya tidak akan bertahan di dunia modern. ${ }^{32}$

Kekhawatiran yang melanda sebagian ilmuan Barat, seharusnya menjadi pelajaran bagi agamawan, ekonom muslim, dan siapa saja yang punya minat dan motivasi untuk mengembangkan ilmu ekonomi Islam karena tidak menutup kemungkinan pengembangan ilmu ekonomi Islam pun akan terhambat lantaran terlalu terbebani dengan wilayah normatif-subjektif dan cenderung ringan dengan aspek yang objektif ilmiah. Sesungguhnya dalam Islam, kehidupan ekonomi dan agama merupakan satu kesatuan yang tidak terpisahkan, ${ }^{33}$ tapi dapat dibedakan. Keduanya berhubungan secara dialektis tanpa berhenti pada satu sisi. Keduanya menyatu menjadi satu kesatuan yang flowing dan fluid tetapi tidak macet dalam satu sisi. Jika tidak demikian, akan terjadi proses dominasi yang satu atas lainnya, sehingga menepikan aspek keilmiahan atau sebaliknya akan menepikan aspek normativitas yang sarat akan nilainilai untuk kesejahteraan. ${ }^{34}$ Secara metodologis, pengembangan ekonomi Islam secara normatif-idealis-deduktif bukanlah sesuatu yang salah, namun hanya akan menjadikan ekonomi Islam sebatas ekonomi etik atau ekonomi yang bermoral, yang kerapakali hanya bisa menjadi pengkritik saja. Dalam rangka merumuskan sebuah sistem yang bisa dijadikan sebagai postulat pengembangan ekonomi Islam, diperlukan adanya metode historis-empiris-induktif berdasarkan realitas dan emperikal aktivitas perekonomian masyarakat yang sedang berkembang.

${ }^{31}$ Akhmad Minhaji (2008), “Ekonomi dan Lembaga Keuangan Islam (Perspektif SejarabSosial)", dalam Abraham L. Udovitch (2008), Kerjasama Syariah dan Bagi Untung-rugi dalam Sejarah Islam Abad Pertengahan (Teori dan Penerapannya) (Kediri: Qubah), p. xiv.

${ }^{32}$ Muhammad (2009), Ekonomi Islam..., p. 123.

${ }^{33}$ Dalam sejarah ekonomi Barat, setidaknya sampai akhir tahuan 1700-an, para ahli ekonomi Eropa adalah pendeta dan ahli, sebagaimana Thomas Aquinas, Agustine. Begitu dengan para ekonom Muslim, seperti Imam Hanafi, Al-Ghazali, Ibnu Taymiah, Ibnu Khaldun, dan lain-lain. Baca lebih lanjut Ahmad M. Saefuddin (1984), Studi Nilai-Nilai Sistem Ekonomi Islam (Jakarta: Media Dakwah), p. 7.

${ }^{34}$ Amin Abdullah (1995), Falsafah Kalam..., pp. 19-20. 
Ilmu ekonomi Islam tidak akan berkembang secara berarti dalam mengejar ketertinggalannya juga tidak akan banyak membantu dalam membuahkan hasil yang optimal jika misi keagamaan masih dominan dan kajian yang bersifat objektif ilmiah masih cenderung lamban. Harus diakui bahwa ilmu ekonomi Islam yang pernah ada dari awal perkembangan sejarah Islam hingga sekarang bukanlah sebuah sistem yang sempurna yang lantas bisa diaplikaskan kapan saja. Dengan demikian, perlu untuk dikonseptualisasi seiring dengan perkembangan zaman yang semakin kompleks. Oleh karena itu, agamawan dan ekonom muslim jangan terjebak dengan pola pikir menara gading yang hanya berpikir murni dalam bidangnya tanpa mengaitkan dengan kenyataan yang ada diluarnya karena setiap aktivitas keilmuan ekonomi Islam tidak dapat dilepaskan dari konteks kehidupan sosial kemasyarakatan yang mengitarinya. ${ }^{35}$

Perjalanan dan perkembangan ilmu ekonomi Islam ditinjau secara filosofisepistimologis bergerak lebih tajam ke wilayah bayani ${ }^{36}$ dan $i r f a n i^{37}$ dengan sedikit menomorduakan penggunaan rasio (burbani) secara maksimal. Hal ini tentu tidak senada dengan praktek yang pernah dilakukan pada masa keemasan keilmuan Islam antara tahun $650 \mathrm{M}$ samapai $1100 \mathrm{M}$. Inilah faktor yang diduga oleh berbagai kalangan, memberi imbas ketertinggalan umat Islam dalam bidang ilmu pengetahuan, tak terkecuali dengan ilmu ekonomi Islam. Sebagai perbandingan, kajian epistimologis dalam literatur Barat dapat membuka perspektif baru dalam kajian ilmu ekonomi yang multidimensional. Studi yang dilakukan oleh sejumlah ilmuan menunjukkan bahwa paradigma keilmuan modern (Barat), termasuk pembangunan ekonomi didasarkan pada filsafat positivisme yang rasionalistik-empiris. Ia tidak menerima sesuatu yang bersifat subjektif, kebenaran yang diterima adalah kebenaran positivistik yang dapat diukur dan dijangkau oleh radius inderawi manusia. Kebenaran model ini berlandaskan pada paradigma raionalitas Cartesian dengan semboyannnya yang terkenal cogito ergo sum atau I think, therefore I am (Saya berfikir, karena itu saya ada). ${ }^{38}$

Namun dalam perkembangannya, ilmu ekonomi Barat dihadapkan secara dikotomis dengan nilai trasendental sehingga jargon ilmu ekonomi bebas nilai (value

${ }^{35}$ Yazid Nasrullah (2007), "Peran Ilmu Filsafat terhadap Ilmu Ekonomi dan Pengembangan para Sarjananya," UNISIA Jurnal Ilmu-ilmu Sosial, Vol. XXX, No. 65, September 2007.

${ }^{36}$ Bayani adalah metode pemikiran yang didasarkan otoritas teks (nash) secara langsung atau tidak. Secara langsung artinya memahami teks sebagai pengetahuan jadi dan langsung mengaplikasikan tanpa perlu pemikiran; secara tidak langsung berarti memahami teks sebagai pengetahuan mentah sehingga perlu tafsir dan penalaran. Meski demikian, hal ini bukan berarti akal atau rasio bisa bebas menentukan makna dan maksudnya, tetapi harus bersandarkan teks. Untuk lebih mendalam, baca al-Jabiri (1991), Bunyah al-Aql al-Arabi (Beirut: al-Markaz al-Tsaqafi al-Arabi).

${ }^{37}$ Irfani tidak didasarkan atas teks, tetapi pada kasyf, tersingkapnya rahasia-rahasia realitas oleh Tuhan. Kerana itu, pengeatahuan irfani tidak diperoleh berdasarkan analisis teks tetapi dengan oleh rohani, dimana kesucian hati diharapkan Tuhan akan melimpahkan pengetahuan langsung kepadanya.

${ }^{38}$ Suyatno, Thomas (1997), dkk, Kelembagaan Perbankan. Edisi kedua. (Jakarta : STIE PERBANNAS dan Gramedia Pustaka Utama) p. 22. 
free), tidak saja mempengaruhi di kalangan akademisi, tetapi juga mewarnai praktekpraktek ekonomi masyarakat modern. Nilai trasendental dan nilai humanis yang seharusnya berjalan seirama mengalami fragmentasi dan pada akhirnya nilai trasendental betul-betul mengalami distorsi, alienasi, dan marginalisasi. ${ }^{39}$ Akibatnya kemudian yang ada hanyalah keserakahan yang tidak berujung di satu sisi dan kemelaratan abadi di sisi yang lain.

Belajar dari kesalahan ilmuan Barat yang telah lepas dari nilai yang mengikatnya, maka ekonomi Islam sebagai sebuah bangunan ilmu yang memiliki tujuan duniawi dan ukhrowi, seharusnya lebih meyakinkan unifikasi tersebut dalam perkembangannya. Sebagai ilmu ekonomi yang berbasis nilai dan tidak mengenal dikotomi, maka kehadiran ekonomi Islam diyakini sebagai penawar di tengah persoalan fundamental kemanusiaan yang masih ada karena selain memuat nilai-nilai humanis, juga membawa ruh keadilan. Keadilan merupakan satu hal yang fundamental ketika berbicara masalah transaksi perekonomian karena sesungguhnya ketidakadilan merupakan sumber permamsalahan yang kerap memunculkan ketimpangan, kemiskinan, dan kelaparan.

Dengan demikian, ekonomi Islam tidak hanya terhenti sebagai sebuah nama yang sarat akan nilai-nilai saja, tetapi juga diharapkan mampu melebur sebagai sebuah sistem yang handal dalam mengatur aktivitas perekonomian global yang didasari dengan kajian postivistik-empiris dan lebih bersifat objektif. Terbangunnya sebuah sistem sebagai pengejewantahan unifikasi antara duniawi dan ukbrowi akan mampu menjawab persoalan-persoalan mendasar kemanusiaan. Namun demikian, perlu dicatat bahwa tidak serta merta dengan adanya unifikasi tersebut lantas membawa pada perubahan, sehingga tidak memerlukan segala hal yang mendasarinya. Pengembangan berkelanjutan ilmu ekonomi tanpa dilapisi dengan muatan ajaran agama yang bersifat profetik, deduktif dan normatif, agaknya hanya akan segera terdominasi dan terkooptasi oleh kekuatan hukum ekonomi yang mempunyai logika kepentingannya sendiri. Begitu juga dengan minimnya kajian keilmiahannya secara objektif, akan mengakibatkan keberlanjutan ilmu ekonomi akan tergadaikan.

Berkaitan dengan itu, burbani sebagai salah satu dasar kajian ilmu pengetahuan dalam Islam seharusnya lebih digairahkan, paling tidak untuk mengimbangi bayani dan irfani yang selama ini cenderung lebih banyak digunakan sebagai dasar prospek pengembangan ilmu ekonomi Islam. Banyak fenomena praktek ekonomi Islam yang selama ini didasari dengan pendekatan intuitif. Praktek zakat misalnya hanya dipahami sebatas kewajiban agama, yang barang siapa yang menunaikannya, maka ia dapat pahala, dan barang siapa yang meninggalkannya maka ia akan mendapat dosa. Padahal sebenarnya, kewajiban zakat yang termaktub dalam Alquran adalah tidak lain dan tidak bukan merupakan sebuah sistem agar bisa mengatasi kesenjangan sosial lantaran

${ }^{39}$ Muhammad (2009), Ekonomi Islam..., p. 122. 
ketimpangan yang melanda sebagaian besar manusia. Dalam kajian antropologi ekonomi, para antroplog mengkatagorikan zakat sebagai salah satu fungsi ekonomi pada kajian redistribusi. Inilah salah satu titik yang menjadi perdebatan serius antara ekonomi formalis yang sarat dengan kultur matrealismenya (ekonomi pasar) dengan ekonomi substanstif (ekonomi tradsional) yang muncul sebagai perwujudan solidaritas sosial dan mengantongi nilai-nilai agama, ajaran dan budaya masyarakat yang mewadahinya. ${ }^{40}$

Tentu hal di atas tidaklah salah, karena itu memang sudah konsekuensi logis sebagai akhir cerita, karena tanpa perspektif agama pun sudah dapat dipahami bahwa sistem ekonomi yang dibayangi dengan muatan individualistik, hedonistik pasti akan menimbulkan dosa, dan terjadinya krisis moneter berulang kali sehingga menciptakan kemiskinan, itulah bentuk kongkrit hukuman atas dosanya. Untuk menjawab itu semua, sesungguhnya epistimologi Islam yang meliputi bayani, irfani, dan burbani merupakan tiga serangkai yang tak bisa dipisahkan satu sama lain. Ketiganya berjalan di atas koredor yang seimbang dan proposional, sehingga dengan demikian, perjalanan perkembangan ekonomi Islam dengan sifatnya yang komplementer dan suplementer dapat menjadi kekuatan untuk membangun ekonomi yang handal dan mampu mengatasi permasalahan kemanusiaan fundamental.

\section{Penutup}

Dalam rangka mengembangkan Ekonomi Islam, tidak bisa tidak, pengelaborasian secara objektif ilmiah menjadi suatu yang mutlak. Ekonomi Islam sebagai sebuah disiplin ilmiah (scientific discipline) selayaknya, selain dikaji secara deduktifnormatif yang sarat dengan nilai-nilai, tetapi juga harus dibangun atas dasar kajian induktif yang berbasis rasionalistik-empirik. Keseimbangan kajian secara induktifdeduktif merupakan harga mati yang tidak bisa ditawar-tawar lagi. Pengembangan yang berkelanjutan dari ilmu ekonomi di satu sisi, tanpa dilapisi dengan muatan ajaran agama yang bersifat profetik dan normatif, agaknya hanya akan segera terdominasi dan terkooptasi oleh kekuatan hukum ekonomi yang mempunyai logika kepentingannya sendiri. Di sisi lain, tanpa kajian objektif ilmiah, pengembangan ilmu ekonomi Islam agaknya akan terseok-seok dalam menjawab permalahan aktivitas perekonomian yang semakin kompleks. Filsafat ilmu sebagai sebuah proses pengelaborasian tentang karakteristik disiplin ilmiah (scientific discipline) dan bagaimana cara memperolehnya (epistimic), menjadi hal yang sangat mungkin sekali untuk dijadikan referensi dasar sebagai pengembangan ekonomi Islam

${ }^{40}$ Untuk lebih mendalam baca Sjafri Sairin, dkk. Pengantar Antropologi Ekonomi. Baca juga Abdul Hamid Mahmud Al-Ba'ly (2006), Ekonomi Zakat: Sebuah Kajian Moneter dan Keuangan Syariah (Jakarta: PT Raja Grafindo Persada). 
Ayief Fathurrahman: Prospek Pengembangan Ilmu Ekonomi Islam...

\section{DAFTAR PUSTAKA}

Abdullah, M. Amin (1995), Falsafah Kalam di Era Postmodernisme.Yogyakarta: Pustaka Pelajar

Ali, Fahcry (1991), “Akomodasi Non-Politik Islam Indonesia dalam Struktur Orde Baru”, Prisma, Vol. 20 No. 3, Maret 1991, pp. 87-96.

Bank Indonesia (2002), Cetak Biru Pengembangan Perbankan Syariab Indonesia, Jakarta: Direktorat Perbankan Syariah Bank Indonesia.

Barbour, Ian G. (1966), Issues in Science and Religion, New York: Harper and Torch Book.

Ba'ly, Abdul Hamid Mahmud (2006), Ekonomi Zakat: Sebuab Kajian Moneter dan Keuangan Syariah, Jakarta: PT Raja Grafindo Persada.

Davies, Roy and Davies, Glyn (1996), The History of Money From Ancient Time of Present Day, New York: Oxport University Press.

Dimyati, A. (2007), “Ekonomi Etis: Paradigma Baru Ekonomi Islam”, Jurnal Ekonomi Islam La Riba, Vol.2, No.1, Desember 2007, pp. 153-168.

Effendy, Bahtiar (1998), Islam dan Negara: Transformasi Pemikiran dan Praktik Politik Umat Islam di Indonesia, Jakarta: Paramadina.

Fathurrahman, Ayief (2010), "Meninjau Ulang Landasan NormatifPerbankan Syariah DiIndonesia (Telaah Atas Teori Kontruksi Fikih Klasik)", Jurnal Mawarid, Vol. XI, No.1 Februari-Agustus 2010.

(2010), "Memahami Kebijakan Ekonomi Politik Tiga Khalifah (Ekplorasi Pemikiran Umar bin Khattab, Umarbin Abdul Aziz, Ghazan Khan Sebagai Dasar Pengembangan Ekonomi Islam)", dikutip dari http:// ayieffathurrahman.wordpress.com/2010/11/22/memahami-kebijakan-ekonomipolitik-tiga-khalifah-eksplorasi-pemikiran-ekonomi-umar-bin-khattab-umar-bin-abdulaziz-dan-ghazan-khan-sebagai-dasar-perkembangan-ekonomi-islam/ diakses tanggal 22 November 2010.

Gie, The Liang (2000), Pengantar Filsafat Ilmu, Edisi Kedua, Cetakan Kelima Yogyakarta: Liberty.

Iswadi, Muhammad (2007), "Ekonomi Islam: Kajian Konsep dan Model Pendekatan”, Jurnal Mazahib, Vol. IV, No. 1, Juni 2007, pp. 48-57.

Al-Jabiri, Muhammad Abid (1991), Bunyah al-'Aqlal-'Arabi, Beirut: al-Markaz al-Tsaqafi al-'Arabi.

Suyatno, Thomas, dkk (1997), Kelembagaan Perbankan. Edisi kedua. Jakarta: STIE PERBANNAS dan Gramedia Pustaka Utama.

Karim, Adiwarman Azwar (2006), Sejarah Pemikiran Ekonomi Islam, edisi ketiga, Jakarta: PT Raja Grafindo Persada. 
Minhaji, Akhmad (2008), "Ekonomi dan Lembaga Keuangan Islam(Perspektif Sejarah-Sosiall”, dalam Abraham L. Udovitch (2008), Kerjasama Syariah dan Bagi Untungrugidalam Sejarah Islam Abad Pertengahan (Teoridan Penerapannya) Kediri: Qubah.

Mudzakkir, A. Qohar (2008), "Kapitalisme, Sosialismedan Sistem Ekonomi Indonesia", dikutip dari http://qahar.wordpress.com/2008/03/29/ kapitalisme-sosialismedan-sistem-ekonomi-indonesia/diakses tanggal 15 September 2010.

Muhammad (2009), Ekonomi Islam, Kontribusi Fundamentalisme Islam untuk Ekonomi Islam, Malang: Empatdua.

Nasrullah, Yazid (2007) "Peran Ilmu Filsafat terhadap Ilmu ekonomi dan Pengembangan para Sarjananya,” UNISIA Jurnal Ilmu-ilmu Sosial, Vol. XXX, No. 65, September 2007.

Pontoh, Coen Husain (2007), "Efek Domino Krisis Properti di AS", dikutip dari http://coenpontoh.wordpress.com/2007/09/19/efek-domino-krisis-properti-di-as/ diakses 15 September 2010.

Praja, Juhaya S., (2000), Filsafat Ilmu: Menelusuri Struktur Filsafat Ilmu dan Ilmuilmu Islam, Bandung: Program Pasca Sarjana Institut Agama Islam Negeri (IAIN) Sunan Gunung Djati.

Saefuddin, Ahmad M. (1984), Studi Nilai-Nilai Sistem Ekonomi Islam, Jakarta: Media Dakwah.

Sairin, Sjafri dkk (2002), Pengantar Antroplogi Ekonomi, Yogyakarta: Pustaka Pelajar Offset.

Seabrook, Jeremy (2006), Kemiskinan Global: Kegagalan Model Ekonomi Neoliberalisme, Yogyakarta: Resist Book.

Sharing, Majalah Ekonomi dan Bisnis Syariah Tahun III Edisi 28 April 2009.

Sitompul, Zulkarnain (2002), "Kemungkinan Penerapan Universal Banking System di Indonesia: Kajian dari Perspektif Bank Syariab”, Jurnal Hukum Bisnis, Vol 20, Agustus-September 2002, pp. 1-9, dikutip dari http://zulsitompul.files.wordpress.com/ 2007/06/bank-syariahjhb.pdf diakses tanggal 15 September 2010.

Suriasumantri (1993), Filsafat Ilmu: Sebuah Pengantar Populer, Jakarta: Pustaka Sinar Harapan.

Wikipedia Bahasa Indonesia (2010), "Sosialisme" dikutip dari http:// id.wikipedia.org/wiki/Sosialisme diakses 15 September 2010.

Yusdani, (2007), "Islamisasi Model al-Faruqidan Penerapannya dalam Ilmu Ekonomi Islam di Indonesia (Suatu Kritik Epistemik)", Jurnal Ekonomi Islam La Riba, Vol.1, No.1, Juli 2007, pp. 77-94. 